\title{
Pendampingan Kelembagaan Desa Tangguh Bencana (Destana) pada Desa Rawan Bencana Banjir Lahar Dingin Gunung Kelud di Kecamatan Kasembon
}

\author{
Eko Aristanto ${ }^{1}$, Syarif Hidayatullah ${ }^{2 *}$, Umu Khouroh $^{3}$, Irany Windyastiti ${ }^{4}$, Andi Nugraha ${ }^{5}$ \\ Universitas Merdeka Malang ${ }^{1,2,3,4}$ \\ Universitas Kanjuruhan Malang 5 \\ eko.aristanto@unmer.ac.id, syarif.hidayatullah@unmer.ac.id*,umukhouroh@yahoo.com \\ irany.windhastiti@unmer.ac.id, andi_nu@unikama.ac.id
}

\begin{abstract}
This service activity aims to help institutional strengthening of the Tangguh Disaster Village (Destana) in disaster planning at the village level in the context of increasing preparedness and overcoming the cold lava flood disaster. The activity was carried out in Kasembon Subdistrict with an implementation time of 3 months. The target groups for this activity are village officials, management and members of the disaster management forum, tagana volunteers and informal leaders from Bayam Village, Pondokagung Village and Pandansari Village. The method of implementing this activity is training and assistance with 6 stages of activities including: i) coordination and outreach, ii) participatory community FGDs, iii) disaster management training, iv) tracking disaster-prone areas, v) mentoring in preparing village disaster documents, vi) evaluation implementation of activities. The results of the implementation of the dedication showed that the attendance rate of participants was $86.7 \%$, the participation rate was $80 \%$, the level of understanding of training materials was $73.3 \%$; and the completion rate of disaster documents by 100\%. The main output of this activity is the Gunung Kelud Cold Flood Lava Contingency Plan Document for Bayam Village, Pondokagung Village and Pandansari Village.
\end{abstract}

Keywords: Cold lava flood; Desa Tangguh Bencana; Disaster Document.

\begin{abstract}
Abstrak
Kegiatan pengabdian ini bertujuan membantu perkuatan kelembagaan Desa Tangguh Bencana (Destana) dalam perencanaan kebencanaan di tingkat desa dalam rangka peningkatan kesiapsiagaan dan penanggulangan bencana banjir lahar dingin. Kegiatan dilaksanakan di Kecamatan Kasembon dengan waktu pelaksanaan selama 3 bulan. Kelompok sasaran kegiatan ini adalah aparat desa, pengurus dan anggota forum penanggulangan bencana, relawan tagana dan tokoh informal dari Desa Bayam, Desa Pondokagung dan Desa Pandansari. Metode pelaksanaan kegiatan ini adalah pelatihan dan pendampingan dengan 6 tahapan kegiatan meliputi : i) koordinasi dan sosialisasi, ii) FGD partisipatif masyarakat, iii) pelatihan manajemen kebencanaan, iv) penelusuran wilayah rawan bencana, v) pendampingan penyusunanan dokumen kebencanaan desa, vi) evaluasi pelaksanaan kegiatan. Hasil pelaksanaan pengabdian menunjukan bahwa tingkat kehadiran peserta sebesar $86,7 \%$, tingkat partisipasi sebesar $80 \%$, tingkat pemahaman materi pelatihan sebesar 73,3\%; dan tingkat penyelesaian dokumen kebencanaan sebesar 100\%. Keluaran utama kegiatan ini adalah Dokumen Rencana Kontigensi Bencana Lahar Banjir Dingin Gunung Kelud bagi Desa Bayam, Desa Pondokagung dan Desa Pandansari.
\end{abstract}

Kata Kunci: Banjir Lahar Dingin; Desa Tangguh Bencana; Dokumen Kebencanaan. 


\section{A. PENDAHULUAN}

Gunung Kelud merupakan gunung berapi aktif yang berada di wilayah Jawa Timur, tepatnya berada di perbatasan antara Kabupaten Kediri, Kabupaten Blitar dan Kabupaten Malang. Data Pusat Vulkanologi dan Mitigasi Bencana Geologi (PVMBG) terkait dengan letusan Gunung Kelud tanggal 13 Februari 2014 merupakan terbesar sepanjang sejarah letusan Gunung Kelud dengan lontaran material dan debu vulkanik menyebar sampai ke Jawa Barat. Kondisi tersebut mengakibatkan ancaman bencana langsung bagi penduduk yang berada di sekitar Gunung Kelud. Dengan mendasarkan kondisi tersebut, menjelaskan bahwa daerah di sekitar Gunung Kelud pada sisi wilayah Kabupaten Malang merupakan kawasan yang rawan terhadap bahaya primer (Erupsi Gunung Kelud) maupun bahaya sekunder (Banjir Lahar Hujan) (Santosa dkk., 2012).

Potensi banjir lahar dingin menjadi ancaman pasca letusan Gunung Kelud yang memungkinan terjadi setiap saat. Hal tersebut dikarenakan sisa material endapan lava dan abu vulanik dalam jutaan kubik yang mengendap di sungai-sungai kecil yang bermuara pada Sungai Kali Konto . Hal inilah menjadi ancaman bencana bagi masyarakat di sepanjang DAS Kali Konto manakala terjadi curah hujan yang tinggi mengakibatkan arus sungai semakin deras sehingga membawa material dan abu vulkanik tersebut menjadi banjir lahar dingin(Astutik dkk., 2014; Nugroho 2014). Berdasarkan data BPBD Kabupaten Malang menjelasan bahwa terdapat 2 Kecamatan yang berisiko terhadap banjir lahar dingin Gunung Kelud tersebut yakni Kecamatan Ngantang dan Kecamatan Kasembon.

Dengan potensi bencana yang dihadapi oleh masyarakat Kecamatan Kasembon tersebut, maka kesiapsiagaan masyarakat dan aparat pemerintah tingkat desa menjadi penting. Hal tersebut, menjelaskan bahwa perencanaan kebencanaan menjadi penting bagi masyarakat yang memiliki daerah dengan tingkat kerawanan yang tinggi. Upaya pemerintah untuk mendorong pengurangan risiko bencana berbasis masyarakat sehingga tangguh terhadap bencana. Dalam Perka BNPN No.1 Tahun 2012 dijelaskan bahwa yang dimaksud Desa Tangguh Bencana adalah desa yang memiliki kemampuan mandiri untuk beradaptasi dan menghadapi potensi ancaman bencana, serta memulihkan diri dengan segera dari dampak-dampak bencana yang merugikan (Oktari, 2019).

Dalam kegiatan pengabdian ini, masyarakat dilibatkan secara partisipatif, maka dukungan modal sosial dan modal sumberdaya manusia di wilayah pengabdian untuk merumuskan berbagai kegiatan perencanaan kebencanaan sangat dibutuhkan. Hal ini bertujuan untuk meminimalkan hambatan upaya penanggulangan risiko bencana yang ada dan untuk mensosialisasikan kepada masyarakat bahwa upaya penanggulangan bencana tetap dapat berkelanjutan walaupun tidak harus terpaku pada aparat pemerintah desa dan ketersediaan dana saja.

Data BPBD Kabupaten Malang menjelaskan wilayah Kecamatan Kasembon terdapat 3 (tiga) desa yang mengalami dan berpotensi terdampak kembali banjir lahar dingin Gunung Kelud adalah Desa Bayem (Badan Nasional Penanggulangan Bencana, 2017), Desa Pondokagung dan Desa Pandansari dengan seluruhan dusun terdampak sebanyak 10 (sepuluh) Dusun (Farid dkk., 2018). Adapun kelompok risiko bencana lahar dingin terbagi menjadi 3 (tiga) yakni tinggi, sedang dan rendah dengan sebarannya dapat dilihat pada Tabel 1. 
Tabel 1. Daftar Dusun sesuai Kelompok Risiko Bencana Banjir Lahar Dingin

\begin{tabular}{lll}
\hline Desa & Dusun & $\begin{array}{l}\text { Kelompok } \\
\text { Risiko }\end{array}$ \\
\hline Bayem & Bulung & Tinggi \\
\hline Pondokagung & Gobed & Rendah \\
& Rekesan & Rendah \\
& Bocok & Tinggi \\
& Sambirejo & Tinggi \\
& Pondok & Sedang \\
& Druju & Rendah \\
\hline Pandansari & Kajang & Tinggi \\
& Sumbersuko & Sedang \\
& Pulosari & Rendah \\
\hline
\end{tabular}

Sumber : BPBD Kabupaten Malang, 2019

Analisis situasi dan tinjauan berbagai informasi yang berkaitan dengan kondisi Desa Tangguh Bencana di Desa Bayem, Desa Pondokagung dan Desa Pandansari ditemukan beberapa hal yakni : 1) pemerintah desa belum memiliki peta rawan ancaman bencana banjir lahar dingin yang melewati sungai Kali Konto, 2) minimnya informasi dan pemahaman tentang manajemen kebencanaan dan penggulangan kebencanaan, 3) minimnya kesadaran masyarakat tentang dampak 4) minimnya dokumen perencanaan kesiapsiagaan penanggulangan bencana di tingkat desa. Berdasarkan analisis situasi tersebut di atas, diperlukan penguatan kelembagaan Desa Tangguh Bencana dalam rangka meningkatan kapasitas kesiapsiagaan dan pengurangan risiko bencana berbasis masyarakat sehingga tangguh terhadap bencana di Desa Bayem, Desa Pondokagung dan Desa Pandansari (Sukmana, 2018; Purnomo, 2017).

\section{B. PELAKSAAAN DAN METODE}

Pelaksanaan pengabdian ini dilaksanakan di Aula Kecamatan Kasembon, Kabupaten Malang dan Balai Desa Bayem. Peserta pengabdian ini adalah aparat pemerintah desa, forum PRB, relawan tagana dan tokoh informal dari Desa Bayem, Desa Pondokagung dan Desa Pandansari sejumlah 30 orang. Metode yang digunakan dalam pengabdian selama 3 bulan adalah focus group discussion (FGD), pelatihan dan pendampingan. Focus Group Discussion (FGD) dalam kegiatan ini dalam mendapatkan masukan dan arahan(Aristanto et al., 2020). Metode desk studi dalam kegiatan ini dilakukan oleh enumerator untuk mengkompilasi berbagai kebutuhan data dan informasi (Hidayatullah dkk., 2019; Aristanto, 2019). Participatory Rural Appraisal (PRA), dalam kegiatan ini dilakukan bersama aparat dusun dan desa terdampak untuk memastikan data-data kewilayahan (Rachmawati dkk., 2018).

Adapun alur tahapan pengabdian pendampingan penguatan Desa Tangguh Bencana (Destana) di Kecamatan Kasembon, Kabupaten Malang sebagai berikut :

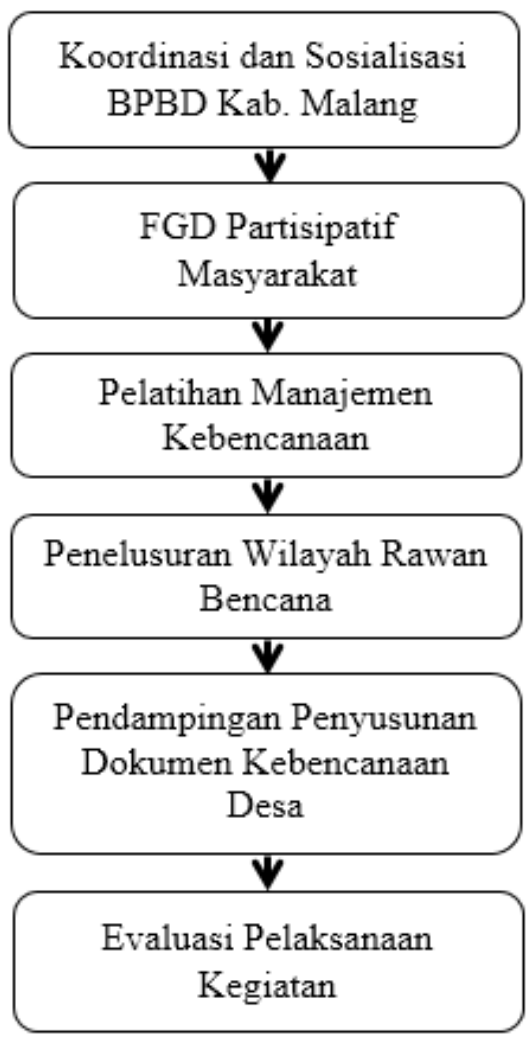

Gambar 1. Alur Tahapan Kegiatan Pendampingan Penguatan Desa Tangguh Bencana 


\section{HASIL DAN PEMBAHASAN}

Pelaksanaan kegiatan ini dimulai dengan melakukan koordinasi antara Tim pengabdian dengan BPBD Kabupaten Malang yang diwakili Bapak Drs. Joni Samsul Hadi, MM (Kepala Bidang Pencegahan dan Kesiapsiagaan) di Kantor BPBD dengan materi koordinasi berkaitan dengan kondisi eksisting dan persiapan pendampingan Desa Tangguh Bencana (Destana) di Desa Bayem, Desa Pondokagung dan Desa Pandansari Kecamatan Kasembon Kabupaten Malang. Hasil kegiatan koordinasi tersebut di sepakati perencanaan kegiatan focus group discussion (FGD) partisipatif masyarakat dengan peserta adalah aparat pemerintah desa, forum PRB, relawan tagana dan tokoh informal dari Desa Bayem, Desa Pondokagung dan Desa Pandansari. Untuk peserta kegiatan pengabdian ini, masing-masing Desa Tangguh Bencana diwakili oleh 10 orang peserta, 3 (tiga) perwakilan dari aparat kecamatan Kasembon dan 2 (dua) aparat keamanan yakni Polsek Kasembon dan Koramil Kasembon, 1 (satu) perwakilan Puskesmas Kasembon dan 3 (satu) perwakilan Babinsa/Babinkamtibmas masing-masing desa. Dengan demikian jumlah peserta yang diundang kegiatan kegiatan focus group discussion (FGD) partisipatif masyarakat sebanyak 39 orang.

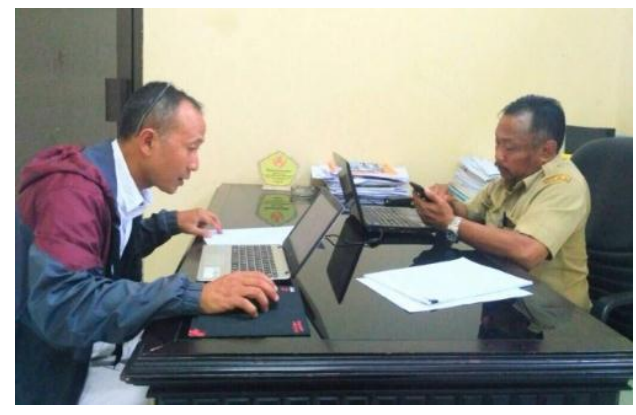

Gambar 2. Koordinasi dan Persiapan Kegiatan FGD Partisipatif Masyarakat dengan BPBD Kabupaten Malang
Kegiatan tahap kedua adalah focus group discussion (FGD) partisipatif masyarakat yang dilaksanaan di Aula Kecamatan Kasembon Kabupaten Malang. Kegiatan ini tujuan untuk mengetahui pemahaman aparat pemerintah desa, forum PRB, relawan tagana dan tokoh informal dari Desa Bayem, Desa Pondokagung dan Desa Pandansari tentang manajemen bencana, kesiapsiagaan terhadap bencana banjir lahar dingin. Dalam kegiatan focus group discussion (FGD) partisipatif masyarakat ini disepakati beberapa hal yang akan dilakukan dalam rangka penguatan kelembagaan Desa Tangguh Bencana (Tagana) Desa Bayem, Desa Pondokagung dan Desa Pandansari meliputi: 1) Tersusunnya peta wilayah berpotensi terdampak bencana banjir lahar dingin pada masing-masing desa; 2) Melakukan kegiatan identifikasi sektor-sektor (permukiman, infrastruktur, sosial, ekonomi dan lintas sektor) yang kemungkinan mengalami kerusakan terdampak bencana banjir lahar dingin; 3) Melakukan penyusunan bersama dokumen perencanaan kebencaan desa yang berkaitan dengan ancaman banjir lahar dingin Gunung Kelud.

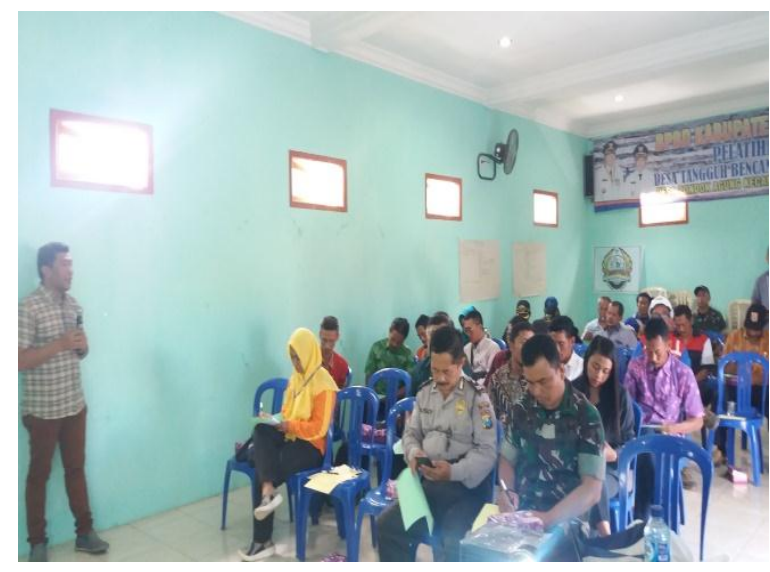

Gambar 3. Pelaksanaan Kegiatan FGD Partisipasi Masyarakat di Kecamatan Kasembon

Kegiatan tahap ketiga adalah Pelatihan Manajemen Kebencanaan. Kegiatan 
pelatihan manajemen kebencanaan ini dapat memberian informasi tentang kesiapsiagaan dan penanggulangan bencana khususnya banjir lahar dingin Gunung Kelud. Pelatihan ini diperuntukan bagi aparat pemerintah desa, forum PRB, relawan tagana dan tokoh informal dari Desa Bayem, Desa Pondokagung dan Desa Pandansari sejumlah 30 orang. Adapun materi yang disampaikan dalam kegiatan pelatihan ini meliputi : a) Dasar-dasar dan tata kelola manajemen bencana. b) Kemungkinan dampak Bencana Banjir Lahar Dingin Gunung Kelud. c) Dampak Bencana Metode penilaian kerusakan dan kerugian metode Jitupasna. d) Menyusun dokumen perencanaan kebencanaan desa. e) Penanggulangan bencana berbasis masyarakat dan penguatan Desa Tangguh Bencana.

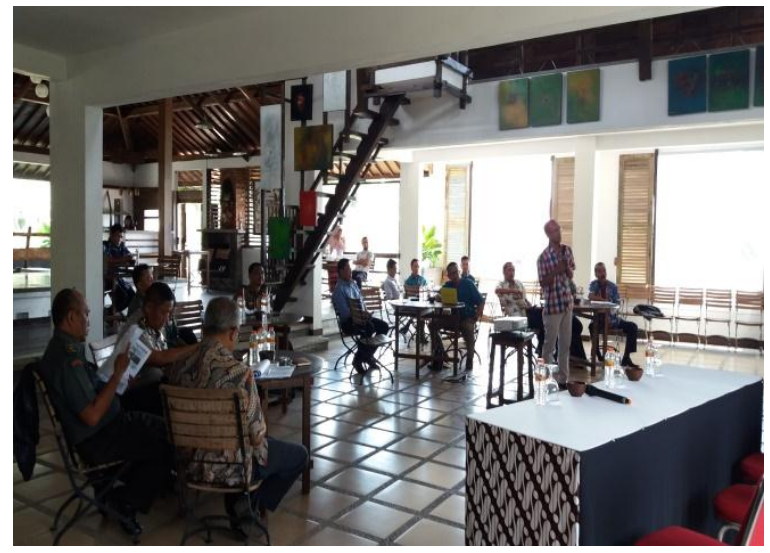

Gambar 4. Pelaksanaan Pelatihan Manajemen Kebencanaan di Kecamatan Kasembon

Kegiatan tahap keempat adalah Kegiatan Penelusuran Potensi Wilayah Terdampak Banjir Lahar Dingin. Kegiatan ini bertujuan untuk memetakan daerah terdampak dan menginventarisir kemungkinan kerusakan pada sektor permukiman, sektor infrastrukrur, sektor ekonomi, sektor sosial dan lintas sektor. Kegiatan ini dilakukan oleh 30 surveyor dan didampingi oleh kepala dusun masing-masing dalam proses Penelusuran Potensi Wilayah Terdampak
Banjir Lahar Dingin. Dalam kegiatan ini memiliki keluaran, sebagai berikut : a) Peta dasar wilayah terdampak kebencanaan banjir lahar dingin. b) Data potensi kerusakan perumahan penduduk yang berisiko terdampak tinggi, sedang dan rendah. c) Data potensi kerusakan infrastruktur, sarana sosial, sarana pendidikan dan sarana kesehatan yang bencana. d) Rencana jalur evakuasi kemungkinan kejadian banjir lahar dingin. e) Data sebaran tempat penampungan sementara (shelter) bagi masyarakat terdampak bencanan banjir lahar dingin.

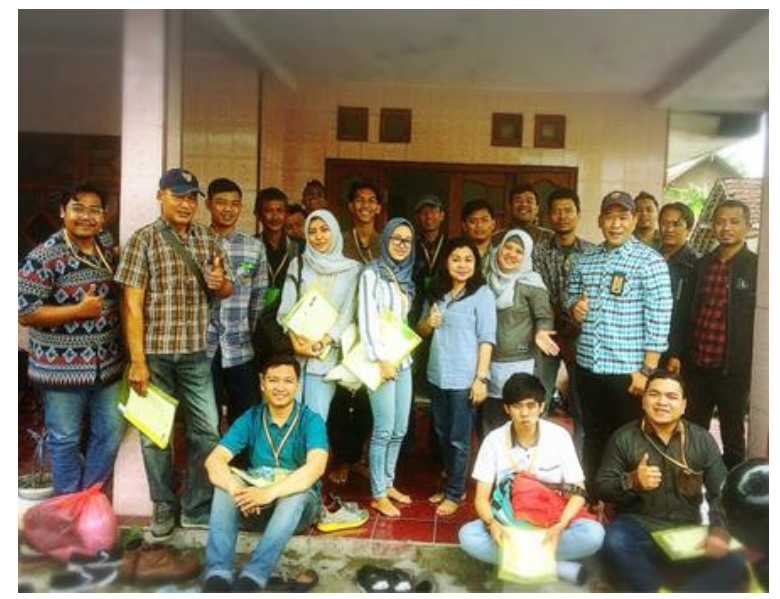

Gambar 5. Surveyor Pemetaaan Potensi Wilayah Terdampak Banjir Lahar Dingin
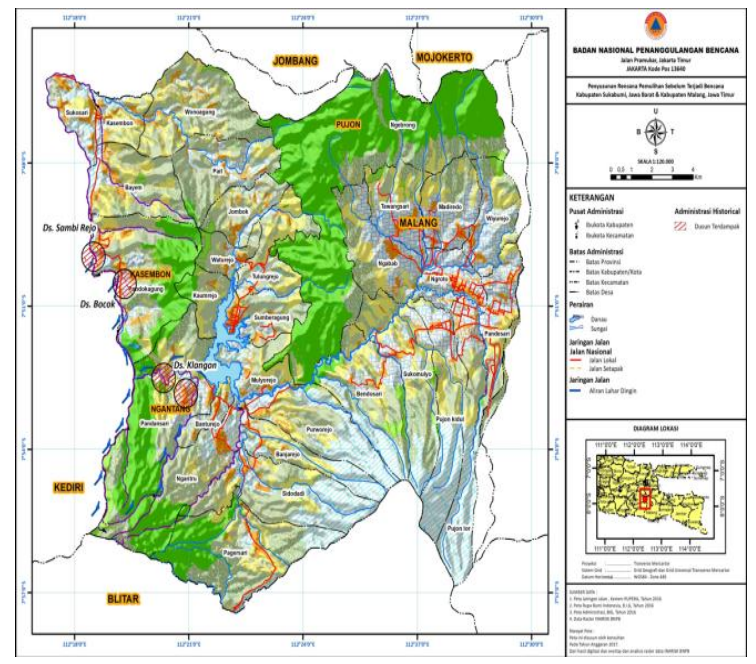

Gambar 6. Peta Wilayah Terdampak Banjir Lahar Dingin Gunung Kelud di Kecamatan Kasembon 
Tabel 2. Jumlah Perumahan Terdampak Bencana Banjir Lahar Dingin

\begin{tabular}{llc}
\hline Desa & Dusun & $\begin{array}{l}\text { Jumlah } \\
\text { Perumahan } \\
\text { Terdampak }\end{array}$ \\
\hline Bayem & Bulung & 40 \\
\hline Pondokagung & Gobed & 294 \\
& Rekesan & 201 \\
& Bocok & 305 \\
& Sambirejo & 120 \\
& Pondok & 304 \\
& Druju & 95 \\
\hline Pandansari & Kajang & 230 \\
& Sumbersuko & 248 \\
& Pulosari & 556 \\
\hline
\end{tabular}

Sumber : Penelusuran dan Pemetaan Wilayah, 2019

Tabel 3. Daftar Lokasi Tempat Pengungsian Sementara Bagi Masyarakat Bencana Banjir Lahar Dingin

\begin{tabular}{lll}
\hline Desa & Dusun & $\begin{array}{l}\text { Tempat } \\
\text { Pengungsian }\end{array}$ \\
\hline Bayem & Bulung & Balai Desa \\
\hline Pondokagung & Gobed & - \\
& Rekesan & - \\
& Bocok & Mushola \\
& Sambirejo & Masjid \\
& Pondok & SD \\
& & Pondokagung \\
& & I dan \\
& Druju & Madrasah \\
& & Diniyah \\
\hline Pandansari & Kajang & SMP \\
& & Kasembon, \\
& & Balai Desa, \\
& & Balai Dusun, \\
& & SMK, SD \\
& & Kasembon 1 \\
& & \& 2 \\
& & - \\
& Sumbersuko & Balai Desa, \\
& Pulosari & Balai Dusun \\
\hline
\end{tabular}

Sumber : Penelusuran dan Pemetaan Wilayah, 2019

Kegiatan tahap kelima adalah Penyusunan Dokumen Kebencanaan Desa. Dokumen tersebut berbentuk Dokumen Rencana
Kontijensi adalah rencana yang disusun untuk menghadapi suatu situasi krisis yang diperkirakan akan segera terjadi, tetapi dapat pula tidak terjadi. Adapun subtansi yang disusun dalam Dokumen Rencana Kontijensi meliputi :

1. Simulasi dan Pengembangan Skenario Kejadian Bencana Banjir Lahar Dingin.

2. Data jumlah Potensi Penduduk Terpapar risiko bencana.

3. Data jumlah perumahan, infrastruktur, sarana sosial, sarana perekonomian dan lintas sektor.

4. Kebijakan dan Strategi Penanganan Bencana Banjir Lahar Dingin.

5. Perencanaan Sektoral Pelaksanaan Kegiatan Evaluasi dan Penyelamatan

6. Rencana Tindak Lanjut.

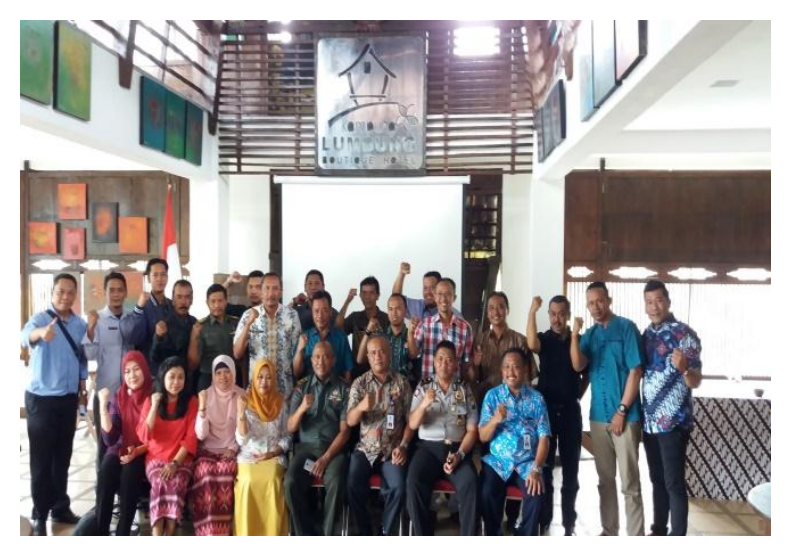

Gambar 7. Diskusi Finalisasi Dokumen Kebencanaan Tingkat Desa

Kegiatan tahap akhir adalah Evaluasi Pelaksanaan Kegiatan. Evaluasi kegiatan ini mengunakan 4 (empat) indikator meliputi : i) tingkat kehadiran peserta dalam kegiatan pelatihan, ii) tingkat pemahaman peserta terhadap berbagai materi kegiatan, iii) tingkat partisipasi peserta, iv) tingkat terselesaikan dokumen kebencanaan tingkat desa. Hasil pelaksanaan pengabdian menunjukan bahwa tingkat kehadiran peserta secara rara-rata pada seluruh kegiatan pertemuan sebesar $86,7 \%$, tingkat partisipasi 
peserta secara rata-rata dalam setiap kegiatan sebesar $80 \%$, tingkat pemahaman peserta terhadap materi manajemen kebencanaan yang disampaikan dalam pelatihan sebesar 73,3\%; dan tingkat penyelesaian dokumen kebencanaan sebesar $100 \%$ menunjukkan dokumen yang menjadi keluaran kegiatan telah terselesaikan.

\section{PENUTUP}

\section{Simpulan}

Kegiatan pengabdian ini telah dapat diselesaikan sesuai dengan rencana kerja yang telah disusun tim pengabdi. Hasil utama yang dapat diperoleh tingkat pemahaman peserta terhadap materi manajemen kebencanaan yang disampaikan dalam pelatihan sebesar 73,3\% menunjukan masyarakat mempunyai tingkat kepedulian untuk memahami kebencanaan di tengah lingkungan tinggal yang berisiko ancaman bencana banjir lahar dingin ("Rancang Bangun Sistem Pengukur Curah Hujan Jarak-Jauh Real Time Sebagai Peringatan Banjir Lahar Dingin," 2010). Dapat terselesaikannya Dokumen Rencana Kontijensi Bencana Banjir lahar Dingin yang menjadi dokumen dan panduan kebencanan di tingkat desa yang menjadi kebutuhan dalam penguatan kelembagaan Desa Tangguh Bencana (Destana) di Desa Bayam, Desa Pondokagung dan Desa Pandansari.

\section{Saran}

Saran yang dapat diberikan dalam kegiatan ini dalam rangka peningatan kelembagaan Desa Tanguh Bencana dan mendorong kesiapsiagaan masyarakat di wilayah berpotensi banjir lahar dingin, sebagai berikut : 1) Mendorong pemerintah desa mensosialisasikan peta wilayah terdampak banjir lahar dingin kepada masyarakat dan relawan tagana; 2) Mendorong kepala desa Bayem, Pondokagung dan Pandansari melaksanakan program kebencanaan dengan mengunakan sumber pendanaan Dana Desa; 3) Bersama masyarakat melakukan simulasi kejadian bencana banjir lahar dingin untuk membangun kesiapsiagaan masyarakat.

\section{Ucapan Terima Kasih}

Tim pelaksana pengabdian menyampai kan terima kasih kepada Direktur Pemulihan dan Peningkatan Sosial Ekonomi, Kedeputian Rehabilitasi dan Rekonstruksi, BNPB dan Kepala Badan Penanggulangan Bencana Daerah (BPBD) Kabupaten Malang atas dukungan pendanaan dan kesediaan waktu mendamping kegiatan ini. Selanjutnya ucapan terima kasih kepada Lembaga Penelitian dan Pengabdian Masyaraat Universitas Merdeka Malang yang telah mendukung pelaksanaan kegiatan ini.

\section{E. DAFTAR PUSTAKA}

Aristanto, E. 2019. Optimalisasi Peran Pemerintah Daerah dalam Mendukung Penyaluran Kredit Usaha Rakyat di Jawa Timur. Jurnal Manajemen Dan Kewirausahaan.

Aristanto, E., Hidayatullah, S., Rachmawati, I. K., \& Waris, A. 2020. Peningkatan fasilitas bagi tahfizh anak usia dini "kuttab rumah quran" menuju persaingan pendidikan anak pra sekolah. 3(1), 78-86.

Astutik, K. P., Suprayogo, D., \& Prijono, S. 2014. Skenario Penggunaan Lahan Melalui Aplikasi Model Genriver untuk Memprediksi Kemampuan Menyangga Cadangan Air di DAS Kali Konto Hulu, Kabupaten Malang. Seminar Nasional Pengelolaan DAS Terpadu Untuk Kesejahteraan Masyarakat. 
Badan Nasional Penanggulangan Bencana. 2017. Jurnal Dialog Penanggulangan Bencana. Jurnal Dialog Penanggulangan Bencana.

Farid, A., Romadi, U., \& Witono, D. 2018. Faktor-Faktor yang Mempengaruhi Adopsi Petani dalam Penerapan Sistem Tanam Jajar Legowo di Desa Sukosari Kecamatan Kasembon Kabupaten Malang Provinsi Jawa Timur. Jurnal Penyuluhan.

Hidayatullah, S., Windhyastiti, I., Aristanto, E., Khouroh, U., \& Kusdyah, I. 2019. PKM Kopi Rakyat Kelompok Wanita Tani ( KWT) "Ngudi Rahayu " Desa Kebobang Wonosari Kabupaten Malang. 4(1), 130-136.

Nugroho, K., Hari, P. 2014. Analisis Tingkat Kerawanan Banjir Sub Daerah Aliran Sungai Gunting Kabupaten Jombang. Swara Bhumi.

Oktari, R. S. 2019. Peningkatan Kapasitas Desa Tangguh Bencana. Jurnal Pengabdian Kepada Masyarakat (Indonesian Journal of Community Engagement).

Purnomo, A. 2017. Geo-Literacy Masyarakat Di Kawasan Rawan Bencana Gunungapi (Studi pada Masyarakat Desa Pandansari Kabupaten Malang). Geo Maritim: Upaya Mewujudkan Poros Maritim Dunia Dalam Perspektif Geografi.
Rachmawati, I. K., Isvandiari, A., Andini, T. D., \& Hidayatullah, S. 2018. PKM. Peningkatan Usaha Jamu Saritoga Ukm "Prayogo" dan Karang Taruna "Bhakti" Dusun Lopawon Desa Kebobang Wonosari Kabupaten Malang. JAPI (Jurnal Akses Pengabdian Indonesia).

Rancang Bangun Sistem Pengukur Curah Hujan Jarak-Jauh Real Time Sebagai Peringatan Banjir Lahar Dingin. 2010. Forum Teknik.

Santosa, B. J., Mashuri, M., Sutrisno, W. T., Wafi, A., Salim, R., \& Armi, R. 2012. Interpretasi Metode Magnetik Untuk Penentuan Struktur Bawah Permukaan Di Sekitar Gunung Kelud Kabupaten Kediri. Jurnal Penelitian Fisika Dan Aplikasinya (JPFA).

Sukmana, O. 2018. Pengetahuan Dan Nilai Kearifan Sosial Dalam Proses Manajemen Bencana Gunung Kelud (Studi di Desa Pandansari, Kecamatan Ngantang, Kabupaten Malang). Sosio Konsepsia. 